\title{
INSUFFICIENT PREPARATION OF TEACHING READING: WHAT SHOULD TEACHER CHALLENGE?
}

\author{
Imroatus Solikhah \\ IAIN Surakarta \\ Jl. Pandawa, Pucangan, Kartasura \\ Email: iimqueenoslo@gmail.com
}

\begin{abstract}
This paper for all intents and purposes is to describe issues and challenges of teaching reading in the EFL classroom. Basically, this paper claims that teaching reading and reading competences are failed to achieve and students get insufficient knowledge and skills through reading. Teaching reading has been colored with problems that make students boring. The problems include: Literacy in general word list vocabulary: Difficult vocabulary terms, Academic vocabulary, Complexity of grammar, Inappropriate texts, Complexity of academic text, Reading habits and culture, Lack of schema activation, Lack of motivation to read, Insufficient preparation in teaching reading. This paper proposes alternative to teaching reading in context of academic purposes in the university level.
\end{abstract}

Keywords: reading habits, general word list, academic vocabulary.

DOI: $10.30957 /$ ijolt $\sim 1 . v 3 i 3.499$.

\section{INTRODUCTION}

This paper reviews theories on teaching readings and its drawback in the practice of teaching reading in EFL classroom in the English major in Indonesian universities. Inclusion of problems pertaining to internal the students encounter and the external handicaps the teachers and materials available is emphasized.

Harmer (2007:99) asserts "through reading students get more. Reading can improve students' vocabulary knowledge, on spelling and writing”. Academically, reading is prominent to develop academic skills, critical thinking and academic purposes (Solikhah, 2015). "Reading is not just picking up words, phrases, and sentences written in the text; it is an activation of the prior knowledge students already have in mind. We use our knowledge of the world to understand the text" (Hedge, 2010:9). This paper argues that problems and challenges in teaching reading pertain to the following thus making reading is boring (Yadav, 2014).

- Literacy in general word list vocabulary

- Difficult vocabulary terms

- Academic vocabulary

- Complexity of grammar 
- Inappropriate texts

- Complexity of academic text

- Reading habits and culture

- Lack of schema activation

- Lack of motivation to read

- Insufficient preparation in teaching reading

The main purpose of reading, based on the review of literatures, for instance Nuttall (1985), Baradja (1984), Sadtono (1997), and Hedge (2010) are but a few examples, is to achieve comprehension. Without comprehension, reading is just an activity to decode printed materials with no understanding. With this view in mind, reading should provide readers with meaningful messages that come from the texts. The results of reading can affect the attitude of perception of the readers.

The major objective of English language teaching in Indonesian high school is reading ability. The objective has been set up from the 1994 Curriculum with a little modification in the 2004 English curriculum for secondary school. The 1994 English curriculum outlined that senior high school graduate is supposed to have mastered a total 4,000 vocabulary items. A modification has been made in the 2004 English curriculum that the senior high school graduate should master 2,500 vocabulary items and the junior high school graduates should master 1,000 vocabulary items. The focus of teaching is also modified; the 1994 English curriculum equips students with more reading, and the 2004 Curriculum provides students with communicative competence. In the Curriculum Based-Competency (2007) and Thematic-Based Curriculum (2013) emphasis of reading refers to communicative competence, whose directions are led to achieve informative knowledge (Ministry of Education and Culture, 2017). This statement seems to give more focused reading goal but the indicators to include in the reading is bias.

However, the implementation of the teaching does not change substantially, though the demand of teaching reading in secondary school levels receives more priority. This means that reading ability is important and teaching reading allocates much time in the school context. In spite of the attempt, reading ability of secondary school students is still poor (Sadtono, 1988; Huda, 1994). This is evidence that the teaching of reading comprehension is not successful yet, although new teaching methodologies are offered from time to time.

This paper argues that despite problems of teaching methodologies that the English teachers usually employee, the failure of teaching reading comprehension comes from other factors. The dependent ability of the teaching methodologies where most secondary school English teachers are occupied with the teaching model comes as strong evidence. In this regard, the model of teaching reading is the basic input that the teachers must apply.

In the context of the reading substance, in other side, the problems arise from textual and reader's knowledge (Nuttall, 1985). The textual factors include vocabulary, sentence structure, cohesive devices, discourse markers, and meaning beyond the plain 
sense, such as contextual and pragmatic meanings. In addition, the reader's knowledge involve the amount of previous knowledge a reader brings to a text, and the amount of shared assumptions between the writer and the reader that support the understanding of the texts. This implies that English teachers of secondary schools would perform in a limited range of ability in teaching reading because of the appearance of their individual barriers and practical skills that they have to perform in front of the class.

The limitation of knowledge in reading English texts because of textual problems promotes significant impact for the teachers. Neither the teachers are self-confidence to understand the English texts nor they can easily quote the messages that can be adopted in the teaching. Consequently, the teaching methods the teachers bring to the class are patterned with the methods they received previously. Modifications or creative changes that are different from the patterns are hard to adapt.

\section{FACTS AND ISSUES}

The facts of teaching reading in secondary schools have brought problems to the English teachers is because of some existence conditions. Traditionally, the problems arise from the condition of ineffective classroom. Scholars of Indonesian teaching, such as Sadtono (1997) and Baradja (1984) have put several problems that are responsible on this matter. The problems include: big class size, limited frequency of teaching, low motivated students, unprofessional teachers, and limited teaching facilities.

The problems so far have been a classical matter since from time to time the condition remains unchangeable. Scholars relate the traditional problems with national policy of education that the central government should change. In this matter, the problem is believed to come from the limited education budget that ranges from $10 \%$ to $12 \%$ of Annual National Budget.

The implication of the low budget on education is serious, but the policy still puts programs that provide little substantial contribution. Huge education projects supported by Asian Development Bank and World Bank have contributed loan of around Rp 12 trillions from 1998 to 2003 (World Bank, 2001). Using the finance, Ministry of Education has brought changes in Indonesian contexts, such as trainings for English teachers, training on school based management, curriculum modification, textbook, etc.

Of the changes available, the trainings on teaching methodologies would be the main facts in relation with this paper. The focus is supported with a strong claim that the endeavours to increase teaching quality are still useless. The main reason of the claim relates to a condition that the government does not change the substantial policy of education; rather, the government changes the policy in trivialities.

Issues pertaining to the teaching model are a condition that trainings on teaching methodologies served trivial knowledge that is still controversy and are of opposite for application. Among the trainings, three different trends on teaching methodologies have been emphasized but no specific result is recommended. The trainings that are strongly suggested to be applicable for teaching English skills, particularly reading include 
Communicative Approach, Competence Based Approach, and Contextual Language Teaching Approach.

This issue provides a strong fact that English teachers are confused to apply the relevant teaching strategies in the context of classroom teaching learning processes. In one aspect, the knowledge and experience the teachers brought from their previous studies are irrelevant so they need to be improved with the newly acquired teaching procedures obtained from the trainings. However, when the new experience is applied, various conditions that are of opposite with the new teaching condition exist. What makes the matter worse, the traditional problems of teaching condition in Indonesia really appear. As a result, the teachers are more confused and go with the normal teaching methods they previously implement in their daily classrooms.

The issue of teaching reading and reading comprehension so far is much involved with the reading skills and tradition of exercises in reading. The development of reading exercises normally go with the exercises students equipped to achieve proficiency in reading. The exercises include reading techniques to improve comprehension: skimming, scanning, reading for thorough comprehension, and critical reading. The second issue deal with the development of language skill exercises. In general and prevalent framework, the development of language skill exercises entails vocabulary, grammar/structure, and discourse.

The reading exercises, normally integrate the skimming, scanning, reading thorough comprehension, and critical reading at a graded formulation. Skimming is a quick reading for general drift of a passage. In scanning, the reader is pushing to search more specific information, e.g. date, number, or place. Reading thorough comprehension is reading to master the total message of the writer (Nuttal, 1985; Yadav, 2014). It is a stage that a reader should be able to paraphrase the writer's opinion. The critical reading requires reader full understanding followed with critical argument to receive or reject the ideas on the text. It involves evaluation on the content of the passage.

The skill of comprehension in reading as such, is so far hard to achieve. Problems on vocabulary, grammar and discourse are salient to happen. Virtually all texts in English work with vocabulary items. Teacher is required to work with a strong commitment overcoming students' drawbacks in vocabulary. Limitation of basic vocabulary and ignorance to focus vocabulary teaching are focal to overcome.

Similar to problem on limited vocabulary if knowledge on grammar. Both vocabulary and grammar are the basic knowledge of English the students should develop. Without vocabulary, nothing can be said and without grammar, very little can be expressed. The problems of the basic knowledge on English appear in the discourse and syntax level. The complexity of text representing low frequency of vocabulary and the variety of uses of compound-complex sentences that deal with more clauses is prominent for students' problems. In the discourse level, linearity of discourse and patterns of organization of ideas that are different from the native language, require students intensive practices and treatments. Faulty of equipping themselves to the similar patterns will result low comprehension in reading. 
In general perspective, tthrough reading, people can get a variety of hidden information and knowledge in books and other printed media. In the era of information which is growing very rapidly, the ability to read is increasingly important, because the information is much more written in English. In addition, the progress of electronic printing machines is growing very rapidly that it may make the dissemination of the written information quicker.

The success of teaching reading class is affected of three important factors: the syllabus, the learners, and the teacher. The syllabus contains the instructional objectives, instructional materials, methodology, and the evaluation procedures. The teacher selects in instructional materials and who is responsible for the design, execution, and evaluation of the teaching program. The learners are those who are learning English. Attitude, intelligence, motivation, purposes, learning needs, learning experience, all of these influence the students in learning English.

Carnine, Silbert, and Kameenui (1990) suggest that much of the failure in schools can be attributed to deficits in the instructional system. First, many of the English reading programs do not carefully control the introduction of vocabulary, either in decoding and comprehension exercises. Second, pre-skills of complex strategies review and practice are minimal and are usually insufficient for many students to master new information and skills at a time. Third, teachers are required to cover too many topics every day. Consequently, finding the time to provide adequate reading practice time is difficult. Fourth, teachers are often not trained to place students carefully in students should be intrinsically motivated to learn to read. In other words, the failure in English reading class is because of the deficiency of the instructional system.

Reading failure can be prevented, however, by efficiently organizing instruction, carefully selecting and modifying reading material, and effectively presenting the material. Student learn the reading competencies so that they feel positive about their ability to function in society. In addition, teachers plan their instruction carefully to achieve the expected objectives.

Reading is also a process of translating graphemic string into spoken words (Adams and Collins, 1985). This process is usually ongoing in the beginning of learning to read. The emphasis of reading in this stage is on the perceptual process, that is, to familiarize the correspondence of letter strings to the language sound. Reading in this stage may refer to the bottom-up process, that is begun by identifying features of letters, linked to recognize letters, combined to recognize words, and proceeded to sentences, paragraphs, and text level (Vacca, Vacca \& Gove, 1991). Reading is a process of understanding written language, combining perceptual process and cognitive process (Rumelhart, 1985). Since reading is a process, it starts from viewing the linguistic surface representation and ends with certain ideas or meaning about massages intended by the writer.

\section{THE NATURE OF READING}

In Indonesia where English is taught as a foreign language, the learningteaching of reading is of particular importance. Learners are expected to read a lot if 
they are serious to master English well. This is the cheapest, easiest, and most effective way to acquaint themselves with the language, the customs, the political adherence, the kinship system, the educational system, the beliefs, of English speaking people (Baradja, 1999).

Reading research has recently increased attention to more global reading strategies of reading comprehension. Narrowly, reading can be defined as a skill of reading words and making general statements about what is read. In a broader sense, a definition of reading encompasses a literacy that can inform the thinking of educated citizens, the ability to draw inferences, examine the tone and structure of the text critically, evaluate the message, remember the content and apply the newly acquired knowledge in a flexible and creative way.

Recent research has found that there is very little direct instruction in reading comprehension. When some students were questioned about the study skills, it was apparent from their answers that very few of them were expert readers.

The assumption that many reading teachers have is that once someone can read they will understand what they read. This assumption is often not correct. The facts are although the students can read all the words, his lack of familiarity with the structure of the English language hinders his understanding of the message in the texts.

Traditional comprehension instructions consist mainly of asking questions after a passage has been read, or of vocabulary instruction. A program on study skills typically instructs the reader to use survey and questioning techniques before reading, and apply recitation, reflection and review after reading. Very few are concerned with what students do during the reading to facilitate learning from text, what to do while processing text. Recent research shows that poor readers rarely report active strategies used by better readers. The better readers can anticipate for (1) giving weight to importance and ignoring trivialities, (2) skimming for main points, (3) strategic rereading, (4) questioning, and (5) evaluating or predicting about what is to be read.

\subsection{Definition of Reading}

The dialogues of reading definitions appear in various perspectives, each of which is complimentary. Among the existing theories, reading is defined from the angles of comprehension, interaction of symbols, decoding, mental process, and interactive process.

Harries and Sipay (1984) assert that reading is the meaningful interpretation of printed or written verbal symbols. Reading is a result of interaction between the perception of graphic symbols that represent language and the reader's language skills and knowledge of the world. Reading is not only as a matter of getting meaning from printed verbal symbols but also the interaction between the graphic symbols and the readers' schemata in understanding the text (comprehension).

Primarily, reading is a means of communicating information between the writer and the reader. The reader tries to understand ideas that the writer has put in print (Vacca, Vacca, and Gove, 1991). Reading may involve decoding and comprehension process. Decoding process refers to the process of saying printed words into a 
representation similar to oral language either silently or aloud. In addition, comprehension is the process of understanding the representation (Carnine, Silbert, and Kameenui, 1990).

Reading is a decoding process, a process of translating graphemic strings into spoken words that occurs ongoing in the beginning of learning to read. The emphasis of reading in this state is on the perceptual process, that is, to familiarize the correspondence of letter strings to the language sound (Adams and Collins, 1985). Reading in this stage may refer to the bottom-up process, that is begun by identifying features of letters, linked to recognize letters, combined to recognize words, and proceeded to sentences, paragraphs, and text level processing (Vacca, Vacca \& Gove, 1991).

Reading is not merely sounding the written language into spoken, either orally or silently. Reading is a process of understanding written language (Rumelhart, 1985). Since reading is a process, it starts from viewing the linguistic surface representation and ends with certain ideas or meaning about massages intended by he writer. Thus, reading is the combination of perceptual process and cognitive process.

Goodman (1973:164) asserts that a reader does not use all the information available to him. Reading is a process in which a reader chooses and picks from the available information only enough to select and predict a language structure which is decodable. It is not in any sense a precise perceptual process. Reading is a receptive language process. It starts with a linguistic surface representation encoded by a writer and ends with meaning which the reader constructs.

To comprehend the text a reader needs two kinds of information: visual and nonvisual. Visual information is the written information which must be caught by eyes. Non-visual information is the information involving the relevance of language competence, knowledge about the topic being read, and knowledge of the world about reading. Both visual and non-visual information have reciprocal relationships (Smith, 1985).

Grabe (1988) admits that reading is an interactive process. It is the process of combining textual information with the information a reader brings to a text. In this view the reading process is not simply a matter of extracting information from the text. Rather, it is one in which the reading activates a range of knowledge in the reader's mind that he or she uses. In this regard, reading is viewed as a kind of dialogue between the reader and the text. Understanding of reading is best considered as the interaction that occurs between the reader and the text, an interpretive process.

\subsection{Reading Comprehension}

Comprehension is making a sense out of text (McNeil, 1992). Reading in this case is the result of interaction between the perception of graphic symbols that represent language and the reader's prior knowledge. As the result of interaction reading (comprehension) is a process of getting information from context and combining disparate elements into a new whole. It is a process of using reader's existing knowledge (schemata) to interpret text in order to construe meaning. Reading, therefore, 
involves reader's schemata about the text and reader's ability to identify the text structures to get the meaning of the text comprehensively.

Pearson (1979) admits that reading comprehension involves relating textual information to pre-existing knowledge structures, or schemata. The schemata represents and reflects the background knowledge, experiences, conceptual understandings, attitudes, values, skills, and procedures a reader brings to a reading situation (Vacca, Vacca, and Gove, 1991). A reader must activate a meaning of text, a reader must activate a schemata that fits with information from a text. To get meaning of text, a reader must activate the schemata he already possesses.

Reading involves meaning in the transaction between reader and writer. The act of reading is an empty, vacuous event without meaning (comprehension). Meaning does not lie hidden in the text. The text provides cues that help the reader to construct meaning. Meaning is derived from the transaction, which occurs between the writer of the text and the reader. Reading comprehension is an active process that takes place behind the eyes. How the human brain processes text information is the key to making meaning. From an interactive point of view, information process is often triggered by the knowledge the reader brought to print. Readers build meaning by connecting new knowledge to knowledge they already possess (Vacca, Vacca and Gove, 1991).

Not only must the readers use background knowledge to comprehend, but they also bring into play knowledge about the text itself. As readers mature, they become more sophisticated in recognizing the ways that text selections are organized in expository and narrative writing. To engage in reading is a meaning activity, readers must search for and find structure in everything they read.

In summary, reading is a process of forming meaning from print. Information derived from text and the knowledge of the reader, acts together to get meaning. In reading process, readers can apply the bottom-up, top-down, or interactive process in understanding the text. The models of reading process attempt to describe how the reader uses graphophonemic, syntactic, and semantic information in translating print to meaning. In addition, comprehension as the final products of reading process is a process involving actively constructing meaning among the parts of text and between the text and personal experience of the reader.

\section{PROBLEMS IN TEACHING OF READING}

The problems in teaching reading deal with the teaching techniques and the selection of teaching materials. Some problems evidently appear from the teaching practices; some emerge as issues that not all teachers agree with. Baradja (1999) for example, ventures five facts that exist as issues in teaching reading. This paper, however, has tentatively concluded that the issues are empirical problems in teaching reading context in Indonesia. The problems include (1) the mastery of the basics knowledge, (2) the habit of slow reading, (3) figuring out inferences, implications and main ideas, (4) text selection, and (5) exercises to include.

The discussion of the problems is necessary to refer to the goal of reading. Nuttall (1989:21) posits that the general goal of reading program does not change. The 
goal refers to enable students to read without help unfamiliar authentic texts, at appropriate speed, silently and with adequate understanding. In the context of teaching reading, however, the goal as proposed by Nuttal (1989) brings some questions that the answers are not easily to supply. Baradja (1999) for instance, proposes three main problems to comment Nuttal's (1989) statements. The questions include (1) how can we help our students to achieve their goals?, (2) how can we help our students to arrive at their 'destination' in the shortest possible time?, and (3) can we change the attitude of our students from indifference to loving and enjoying reading?

\subsection{The Mastery of the Basics}

The basic knowledge of reading consists of the mastery of basic structural patterns and sufficient vocabulary items. The basic knowledge is the "foundation of reading" (Baradja, 1999:2). It is quite logic that reading learners must achieve the basic knowledge at appropriate levels. If this is not available, how can be build a house without a foundation?

The condition of teaching reading in Indonesian context releases problems for the students and the teacher. The class is generally very large and with only one meeting a week. Most of the time we use full-fledged textbooks, i.e. economics, biology, since we not able to find simplified texts for our purposes. The teacher herself has to struggle to understand the text, or the teacher does not have an adequate background and habit to read a long English text. The worse, students are not motivated.

\subsection{The Habit of Slow Reading}

Slow readers generally have poor comprehension (Tyllier, 1999). Therefore, slow readers are at a disadvantage in many ways. In Indonesian context, students try to read very slow as if they want to understand every word of the passage. If they do not understand a word or an expression, they do not hesitate to look up word by word in the dictionary so that the reading is very slow.

Complete understanding in a reading process is nonsense (Baradja, 1999). What the readers need in reading is actually to look up meaning of the key words and expression. To achieve this, readers can guess the meaning of the keywords from context. So, the readers need to practice reading speed with understanding. Speed comes from lots of practice reading interesting and lengthy texts. The more we practice, the closer would be our approximation to the intended message of the writer.

\subsection{Figuring out Inferences, Implications, and Main Ideas}

Baradja (1999) posits that in reading an English text, students are concerned with two factors: to decode the text as what the writer says and be familiar with content schema that include culture and background knowledge. The mastery on these factors will provide students with accurate inferences, determining implications of what has been read, and identifying accurately main ideas of the text. Most students do not 
understand the text properly because they could not identify the main idea, make correct inferences, and understand accurate implication.

\subsection{Text Selection}

In the text selection, teachers are not confident to choose the teaching materials. Teachers mostly rely upon English textbook available by which modifications are not required. To use the textbook, the teachers follow the contents and exercises on the book. In this regard, teachers are occupied with teaching target that they have to elicit vocabulary items to be designed in the text, topics of the passage that have been outline in the curriculum, and exercises that have been designed to provide grammar exercises. As a matter of facts, text selection appears difficult matters for the teachers.

\subsection{Exercises to Include}

Exercises following the reading passage have been questioned as they impose the teachers to implement teaching strategies at the artificial same ways. The format of the exercises in the traditional comprehension is following a passage; the writer provides some comprehension questions functioning as guidelines for the learners to understand the text. Normally, multiple-choice items with four options or true-false items are available below the text.

The problems on this matter involve that teachers normally do the same ways inn discussing one passage to another so that students are boring facing the same techniques. Modification to the exercises is hard to do since it wastes time and energy. As a result, a good exercise that includes items that ask for facts or information, inferences, implications, and implicit answers are not available.

\section{DISCUSSION}

The problems on teaching reading to secondary schools in Indonesia deal with three basic conditions, each of which relates to the reading instruction. First of all, classical condition of education in Indonesia in which policy of education affects significantly to arise is of importance priority. The classical condition has appeared for so long time and has received improvement that costs a lot of finance. However, adequate solution to overcome the problems seems to be far cry. The second problems pertain to the facts in teaching reading occurred in the daily classroom activities. This problem refers mostly to the learners' competence in English in general and in comprehension level where basic knowledge on vocabulary, grammar, and schemata play substantial effects. The last point deals with teaching reading strategies where English teachers implement to serve in the classroom. Trainings provided by the government for the teaching of reading are improved and updated from time to time, however, the implementation in the classroom remains unchanged.

Problems relating to traditional condition due to the education policy and facts of classroom instruction have been discussed on the previous sections. The following discussion puts emphasis on the teaching methodology, providing brief inferences on communicative methods and contextual based teaching that is recently popular. 
The existence of communicative method in teaching English has spent much time and energy to English teachers, students, and curriculum designer. In this regard, teaching reading has been outlined to perform a three-step teaching that includes prereading, while reading, and post-reading. The doctrine on the three-step teaching of reading significantly influences to the teaching reading implementation throughout secondary schools in Indonesia. With medium instruction in English, English teachers of secondary schools believe that the doctrine serves excellent results in teaching reading.

The doctrine becomes a main pattern that every teacher of English should follow when teaching reading. However, several studies examining the effectiveness of teaching reading under the model indicate an unexpected result. Neither the teaching pattern in reading is boring, nor students are occupied with artificial procedures where comprehension is often ignored. As a result, the goal of reading to achieve comprehension is not satisfactorily gained.

Following the communicative method, contextual language teaching appears. Like the communicative method where at the first issue becomes trendy and fashionable in the front place, the contextual language teaching seems to indicate prospective result. Trainings on the new methods provided for English teachers are conducted apparently. However, the implementation of teaching reading in the daily classroom activities in the secondary levels remains to appear big questions. Analysis on various evidences indicates that the classical condition of education is of essential. In addition, major problem appears that the teachers' competence on teaching reading and innovation to change the pattern become very significant. The lack of knowledge and background on teaching reading makes English teachers are occupied with patterned teaching models trained before.

\section{CONCLUSION}

Teaching reading model at secondary school level does not change, though various trainings equipping English teachers with new techniques and methods are provided by the government. The communicative methods and contextual language teaching methods are new trend in English teaching methodology that seems superior, but do not provide substantial change in the implementation of teaching reading at school classrooms. Three basic problems appear in line with teachers' attitude: the classical condition of education, facts that students' habits and attitude in reading, and teaching methodology. Of the three problems, teaching methodology is most essential to focus. In other words, the existence of new trend and fashioned teaching methodology apparently shows that they does not promise substantial changes, provided, the basic condition remains unchanged.

\section{REFERENCES}

Adams, M. J. and Collins, A., 1985. "A Schema-theoretic View of Reading”. In Singer, H. and Ruddlel, R. B. (Eds.), Theoretical Models and Processes of Reading. ( ${ }^{\text {rd }}$ ed.), pp. 404-425. New York: International Reading Association. 
IJOTL TL, Vol. 3, No. 3, September 2018

p ISSN: 2502 2326; e ISSN: 2502 8278

Http://ijolt1.pusatbahasa.or.id; Email: ijolt1@gmail.com

Center of Language and Culture Studies, Surakarta, Indonesia

Solikhah, Imroatus. 2018. Insufficient Preparation of Teaching Reading: What Should Teacher Challenge? IJOTL TL (2018), 3(3): 71 84. DOI: 10.30957/ijolt-11.v3i3.499.

Anderson, Richard C. and Pearson, P. David, 1984. A Schema-Theoretic View of Basic Process in Reading Comprehension. In Richard C. Anderson and David P. Pearson. (Eds.) Handbook of Reading. London: Longman.

Anthony, Edward E., 1965. "Approach, Method, and Technique". In Harold G. Allen and N. Cambell. (Eds.) Teaching English as a Second Language. New York: McGraw-Hill International Books Company.

Baradja, M. F. 1984. Kapita Selekta Pengajaran Bahasa. Malang: IKIP Malang.

Bialystok, Ellen. 1990. Communication Strategies: A Psychological Analysis of Second Language Use. New Jersey: Basil Blackwell, Inc.

Brown, H. Douglas, 1987. Principles of Language Learning and Teaching. Second Edition. Englewood Cliffs, N. J.: Prentice-Hall.

Burns, P. C., Roe, B. D. and Ross, E. P., 1984. Teaching Reading in Today's Elementary Schools. ( $3^{\text {rd }}$ ed.), Chicago: Rand McNally College.

Canale, M., 1983. "From Communicative Competence to Communicate Language Pedagogy". In J. C. Richards and R. W. Schmidt (Eds.), Language and Communication, London: Longman.

Carnine, D., Silbert, J., and Kameenui, E. J., 1990. Direct Instruction Reading. $\left(2^{\text {nd }}\right.$ ed.)., New York: Merril Publishing Company.

Carrell, P. L., Devine, J. and Eskey, D. E., 1988. Interaction Approach to Second language Reading. Cambridge: Cambridge University Press.

Chall, J., 1979. Learning to Read: The Great Debate, New York: McGraw-Hill.

Coady, James., 1979. “A Psycholinguistic Model of ESL Reader.” In Ronald Mackay. (Eds.). Reading in Second Language. Massachusetts: Newbury House Publishers, Inc.

Gebhard, J. G., 1987. "Successful Comprehension: What teachers can do before students read". FORUM, Vol. XXV Number 2, April. Pp. $21-23$.

Goodman, K. S. (at al) "The Reading Process". In Careell, P. L., Devine, J. and Eskey, D. E., (Eds.) 1988. Interactive Approach to Second Language Reading. pp. 11 21.

Greenall, S. and Swan, M., 1994. Effective Reading: Teachers' Book. London: Cambridge University Press.

Greenwood, John 1981. Comprehension and Reading. In Gerry Abbott (Ed.) The Reading of English as an International Language: A Practical guide. Glasgow: William Collins Sons and Co. Ltd.

Grellet, Francoise, 1992. Developing Reading Skills: A practical guide to reading comprehension exercise. Cambridge: Cambridge University Press.

Gunning, T. G., 1992. Creating Reading Instruction for All Children. Boston: Allyn and Bacon.

Harris, Albert J. and Sipay, Edward R., 1984. How to Increase Reading Ability: A Guide to Developmental and Remedial Methods. ( $7^{\text {th }}$ ed.), Longman: New York and London.

Harmer, J. 2007. How to teach English. London: Pearson Longman. 
IJOTL TL, Vol. 3, No. 3, September 2018

p ISSN: 2502 2326; e ISSN: 2502 8278

Http://ijolt1.pusatbahasa.or.id; Email: ijolt1@gmail.com

Center of Language and Culture Studies, Surakarta, Indonesia

Solikhah, Imroatus. 2018. Insufficient Preparation of Teaching Reading: What Should Teacher Challenge? IJOTL TL (2018), 3(3): 71 84. DOI: 10.30957/ijolt-11.v3i3.499.

Hedge, T. 2010. Teaching and learning in the language classroom. Oxford: Oxford University Press.

Hudson, T. (2007). Teaching second language reading. Oxford: Oxford University Press.

Littlewood, W. 1981. Communication Language Teaching. Cambridge: Cambridge University Press.

Mason, Jana M. and Au, Kathryn H., 1990. Reading Instruction for Today. (2 ${ }^{\text {nd }}$ ed.). New Jersey: Harper Collins Publishers.

McNeil, John D., 1992. Reading Comprehension: New Direction for Classroom Practice. ( $3^{\text {rd }}$ ed.). New York: Harper Collins Publishers.

Mealey, D. L. and Nist, S. L., 1989. Post-secondary Teacher Directed Comprehension Strategies. Journal of Reading. Vol. 32, Number 6, March. pp. 484-493.

Nuttal, C. 1989. Teaching Reading Skills in a Foreign Language. Oxford: Heinemann.

Otto, Wayne Robert Rude, D. L. Spiegel, 1979. How to Teach Reading. AddisonWesley Publishing Company, Inc.

Perfetti, C., 1985. Reading Ability. New York Oxford.

Rumelhart, D. E., 1985. "Toward an interactive model of reading". In Singer, H. and Ruddell, R. B. (Eds.) Theoretical Models and Process of Reading. ( ${ }^{\text {rd }}$ ed.), pp. 722-750. New York: International Reading Association.

Sadtono, E., 1995. Perspektif Pengajaran Bahasa Inggris di Indonesia. FPBS KIP Malang: Seksi Kajian Bahasa dan Seni.

Solikhah, Imroatus. 2015. Reading and Writing as Academic Literacy in EAP Programs for Indonesian Learners. Dinamika Ilmu, 15(2): 323-339.

Staiger, Ralph C., 1973. The Teaching of Reading. UNISCO: Ginn and Company \& Laxington: A Xerox Education Company.

Stott, N. (2001). Helping students become better readers: schema theory application and limitations. The internet TESL Journal,7(11). Retrieve

from http://iteslj.org/articles/stott-schema.html

Tierney, R. J. and Cunningham, J. W., 1984. Research on Teaching Reading Comprehension, IN Richards C. Pearson and David P. Pearson (Eds.). A Handbook of Reading Research. London: Longman.

Vacca, Jo A. L., Vacca, R. T., and M. K. Gove, 1991. Reading and Learning to Read. ( $2^{\text {nd }}$ ed.), Harper Collins Publishers.

Wiriyachitra, Arunee, 1995. The Roles of the Teacher in the Reading Classroom. FORUM. 33(4): 43-44.

Yadav, Prasad Gyanendra. 2014. Issues and Challenges in Teaching Reading in EFL Classroom. 
IJOTL TL, Vol. 3, No. 3, September 2018

p ISSN: 2502 2326; e ISSN: 2502 8278

Http://ijolt1.pusatbahasa.or.id; Email: ijolt1@gmail.com Center of Language and Culture Studies, Surakarta, Indonesia

Solikhah, Imroatus. 2018. Insufficient Preparation of Teaching Reading: What Should Teacher Challenge? IJOTL TL (2018), 3(3): 71 84. DOI: 10.30957/ijolt tl.v3i3.499. 